\title{
Angiotensin II Induces C-Reactive Protein Expression via AT1-ROS-MAPK-NF-kB Signal Pathway in Hepatocytes
}

\author{
Jingjing Zhao Juntian Liu Xiaoming Pang Shuyue Wang Di Wu Xiaolu Zhang \\ Liuxin Feng
}

Department of Pharmacology, Xi'an Jiaotong University School of Medicine, Xi'an

\author{
Key Words \\ C-reactive protein $\bullet$ Angiotensin II $\bullet$ Hepatocytes $\bullet$ Liver $\bullet$ Inflammation $\bullet$ Atherosclerosis
}

\begin{abstract}
Background: C-reactive protein (CRP) participates in development of inflammatory diseases. Hepatocytes are a major contributor of circulating CRP. Although angiotensin II (Ang II) is known to evoke inflammatory response, it remains unknown whether Ang II induces CRP expression in hepatocytes. The present study observed effect of Ang II on CRP expression and the related signal pathway in hepatocytes. Methods: mRNA and protein expressions in human hepatocytes were determined with RT-PCR and Western blot respectively. Reactive oxygen species (ROS) was measured using a fluorescence probe. CRP in liver and serum of rats was determined by immunohistochemistry and ELISA respectively. Results: Ang II induced mRNA and protein expression of CRP in hepatocytes and increased CRP production in liver and CRP level in serum. Losartan reduced Ang II- induced CRP expression in hepatocytes. Losartan and thenoyltrifluoroacetone decreased Ang II-stimulated ROS production. N-acetylcysteine antagonized Ang II-induced CRP expression. Losartan and $\mathrm{N}$-acetylcysteine inhibited Ang II-activated ERK1/2. Unlike ERK1/2, only losartan inhibited Ang II-activated JNK. Furthermore, pyrrolidine dithiocarbamate abolished Ang II-induced CRP expression. Conclusion: Ang II has ability to induce CRP expression in hepatocytes in vitro and in vivo through AT1 receptor followed by ROS, MAPK and NF-KB signal pathway.
\end{abstract}

Copyright (C) 2013 S. Karger AG, Basel

\section{Introduction}

An impressive amount of data now implicates that inflammatory response is involved in the pathogenesis of cardiovascular diseases. C-reactive protein (CRP) in comparison to other inflammation markers is a relatively stable, robust and an exquisitely sensitive serum 
protein. In some studies, CRP level in plasma predicts cardiovascular events even better than low-density lipoprotein cholesterol level [1]. Multiple epidemiological and mechanistic studies have shown that CRP is not just a marker but rather an active mediator for endothelial dysfunction, arterial thrombosis and atherogenesis [2, 3]. CRP, as an inflammatory cytokine, is primarily synthesized in liver and regulated in response to interleukin-6 (IL-6) and interleukin-1 $\beta$ (IL-1 $\beta$ ) [4-6]. Hepatocytes are believed to be the major contributor of circulating CRP in plasma. Therefore, hepatic CRP is able to cause liver per se damage and inflammation, and plays a key role in the development of atherosclerosis when entering into the blood circulation. In hepatoma cell lines, the endogenous CRP gene is either dysregulated or weakly active [7]. However, plasma levels of CRP may rise rapidly and markedly ( $>1000$ fold) after an acute inflammation in human [8].

Angiotensin II (Ang II), the key mediator of renin-angiotensin system (RAS), is responsible not only for vasoconstriction and sodium homeostasis, but also for production of inflammatory cytokines [9-11]. Besides the actions on cardiovascular system, Ang II has been revealed to play the important roles in extra-cardiovascular organs. Both the systemic and the local RAS is involved in pro-oxidant, pro-inflammatory and profibrogenic processes in the heart, blood vessels, kidney and liver [12]. Moreover, the key elements of RAS are present in normal liver tissue, and the system is upregulated in human and rat livers undergoing active fibrogenesis $[13,14]$. In vitro and in vivo experiments in liver have shown that Ang II is able to induce oxidative stress, synthesis of transforming growth factor- $\beta 1$ and collagen, and to exert proinflammatory actions by stimulating the expression of many proinflammatory cytokines such as intercellular adhesion molecule, IL-6, IL-1 $\beta$, IL-8, tumor necrosis factor-alpha, cyclooxygenase-2 and iNOS $[12,15]$. Our previous work suggested that Ang II may induce CRP expression in rat vascular smooth muscle cells (VSMCs), human aortic endothelial cells (HAECs) and macrophages [16-18].

Although Ang II is known to evoke the inflammatory responses in liver, it remains unknown whether Ang II is capable of inducing CRP expression in hepatocytes. Therefore, the present study examined effect of Ang II on CRP expression in hepatocytes and explored the related signal pathway.

\section{Materials and Methods}

\section{Reagents}

Recombinant human Ang II, PD98059, SP600125, SB203580, N-acetylcysteine (NAC), pyrrolidine dithiocarbamate (PDTC), diphenyleneiodonium (DPI) and thenoyltrifluoroacetone (TTFA) were from Sigma-Aldrich (St. Louis, MO, USA). Recombinant human (rh) IL-6 and IL-1 $\beta$ were produced by Peprotech (NJ, USA). Losartan and PD123319 were obtained from Tocris (Bristol, UK). Polyclonal anti-human C-reactive protein antibody was provided by Abcam (Cambridge, UK). Anti-human IL-1 $\beta$ and anti-human IL-6 neutralizing antibodies were ordered from R\&D Systems (MN, USA). Antibodies against phosphorERK1/2, ERK1/2, phosphor-JNK and JNK were from Beyotime Institute of Biotechnology (Jiangsu, China). Anti-GAPDH monoclonal antibody was supplied by Golden Bridge Biotechnology Company (Beijing, China).

\section{Cell culture}

Human normal liver cell line L-02 was obtained from the Type Culture Collection of the Chinese Academy of Sciences, Shanghai, China. The cells were cultured in a $5 \% \mathrm{CO}_{2}$ atmosphere in RPMI-1640 supplemented with $10 \%$ fetal bovine serum (Hyclone, USA), penicillin $(100 \mathrm{U} / \mathrm{ml})$ and streptomycin $(100$ $\mu \mathrm{g} / \mathrm{ml}$ ). When treated with Ang II or other reagents, the cells were serum-starved for at least $12 \mathrm{~h}$ before the experiments. In the inhibitor experiments, the cells were exposed to Ang II $\left(10^{-6} \mathrm{M}\right)$ for $24 \mathrm{~h}$ after pretreated with the inhibitors for $1 \mathrm{~h}$.

RT-PCR

The total RNA was extracted from the cells using RNA ${ }_{\text {fast200 }}$ (Fastagen, Biotech Co., Ltd, Shanghai, China) according to manufacturer's instruction. The total RNA was quantified by spectrophotometer at 
$260 \mathrm{~nm}$, and assessed for the purity at $280 \mathrm{~nm}$. One microgram of isolated RNA from each sample was reverse-transcribed to cDNA using oligo (dT) 18 primer and RevertAid ${ }^{\mathrm{TM}}$ M-MuLV Reverse Transcriptase (Fermentas, Germany). PCR reactions were performed in a volume of $25 \mu \mathrm{l}$ containing the corresponding sense and antisense primers using the PCR Reagent System (GIBCO-BRL). The cDNA was amplified using $2 \mu \mathrm{l}$ of each of CRP forward primer (5'-TCG TGG AGT TCT GGG TAG ATG-3') and reverse primer (5'-CCG CCA AGA TAG ATG GTG TTA-3'). This resulted in a 217 bp PCR product ( 32 amplification cycles of $94^{\circ} \mathrm{C}$ for $5 \mathrm{~min}, 94^{\circ} \mathrm{C}$ for $30 \mathrm{~s}, 60^{\circ} \mathrm{C}$ for $30 \mathrm{~s}, 72^{\circ} \mathrm{C}$ for $1 \mathrm{~min}$, and $72^{\circ} \mathrm{C}$ for $5 \mathrm{~min}$ ). The housekeeping gene (GAPDH) was amplified as an internal control for normalization using the forward primer (5'-GGA TTT GGT CGT ATT GGG-3') and the reverse primer (5'-GGA AGA TGG TGA TGG GAT T-3'). This resulted in a 205 bp product (32 amplification cycles of $94^{\circ} \mathrm{C}$ for $5 \mathrm{~min}, 94^{\circ} \mathrm{C}$ for $30 \mathrm{~s}, 58^{\circ} \mathrm{C}$ for $30 \mathrm{~s}, 72^{\circ} \mathrm{C}$ for $1 \mathrm{~min}$, and $72^{\circ} \mathrm{C}$ for $5 \mathrm{~min}$ ). All PCR products were separated on $2 \%$ agarose gel electrophoresis and visualized using ethidium bromide staining. Expression of mRNA was quantified as relative to control GAPDH.

\section{Neutralizing experiment}

L-02 cells were treated with rhIL-6 $(25 \mathrm{ng} / \mathrm{ml})$ or/and IL- $1 \beta(25 \mathrm{ng} / \mathrm{ml})$ for $24 \mathrm{~h}$ in the absence or presence of Ang II $\left(10^{-6} \mathrm{M}\right)$. In the another experiment, the cells were pretreated with anti-IL- 6 or/and antiIL-1 $\beta$ neutralizing antibodies $(5 \mu \mathrm{g} / \mathrm{ml})$ for $1 \mathrm{~h}$ prior to Ang II $\left(10^{-6} \mathrm{M}\right)$ stimulation for $24 \mathrm{~h}$ [19]. Finally, CRP was assayed by Western blot.

\section{Western blot analysis}

After treated, L-02 cells were washed and lysed by $200 \mu \mathrm{l}$ ice-cold RIPA lysis buffer containing the protease inhibitor cocktail (Roche, Germany). Protein was quantified by the BCA protein assay kit (Pierce, Rockford, USA). Protein extracts (50 $\mu \mathrm{g}$ ) were resolved on 12\% SDS-PAGE gels, and transferred to nitrocellulose membranes in semi-dry system (Bio-Rad, Hercules, CA). The membranes were blocked with $5 \%$ nonfat dry milk or bovine serum albumin in Tris-buffered saline containing $0.1 \%$ Tween 20 , and incubated with the specific antibodies against CRP (1:250 dilution), phosphor-ERK (1:750 dilution), ERK (1:1000 dilution), phosphor-JNK (1:750 dilution), JNK (1:1000 dilution) and GAPDH (1:1000 dilution) overnight at $4{ }^{\circ} \mathrm{C}$. After the extensive washing, the membranes were incubated with HRP-conjugated antirabbit or anti-mouse antibodies (1:5000 dilution) for $2 \mathrm{~h}$ at room temperature followed by the enhanced chemiluminescence (Pierce). The light signals were detected by X-ray film. Optical density of the bands was scanned and quantified with Gel Doc 2000 (Bio-Rad). GAPDH was used as loading control.

\section{Measurement of intracellular ROS}

Intracellular reactive oxygen species (ROS) in L-02 cells were measured using 2', 7'-dichlorodihydrofluorescein diacetate $\left(\mathrm{H}_{2} \mathrm{DCF}-\mathrm{DA}\right)$ fluorescent labeling method. The cells in 12 well culture plate were exposed to Ang II $\left(10^{-6} \mathrm{M}\right)$ for $6 \mathrm{~h}$ after the pretreatment with losartan $\left(10^{-5} \mathrm{M}\right)$, PD123319 $\left(10^{-5} \mathrm{M}\right)$, TTFA $\left(10^{-5} \mathrm{M}\right)$ or DPI $\left(10^{-5} \mathrm{M}\right)$ for $1 \mathrm{~h}$. Then, the cells were incubated with $\mathrm{H}_{2}$ DCF-DA $(10$ $\mu \mathrm{M})$ for $50 \mathrm{~min}$. The fluorescent intensity was measured by a fluorescence microscope (ECLIPSE Ti, Nikon, Japan) at the excitation wavelength of $488 \mathrm{~nm}$ and emission wavelength of $525 \mathrm{~nm}$. Fluorescence intensity of the experimental field was measured and analyzed from the fluorescence images with the Image-pro plus software. The relative fluorescence intensity was taken as the average of values from three repeated experiments.

\section{Immunohistochemical staining}

Male Sprague-Dawley rats (wt. 200-220 g) were anesthetized with methoxyflurane and subcutaneously implanted with osmotic minipumps (Model 2001, Durect Corporation, Cupertino, CA, USA). Then, rats in Ang II-treated group and control group were respectively delivered with Ang II (120 ng/kg/min, n=6) or $0.9 \%$ saline $(n=6)$ for 7 days. During the infusion, body weight and the systolic blood pressure were measured everyday. Rats were weighed and killed, and liver and blood samples were harvested in the end of the infusion period. Serum was separated for measuring CRP with ELISA kit (Bender Med Systems). Liver tissues were fixed in $4 \%$ paraformaldehyde, embedded in paraffin, and cut into 5 - $\mu$ m-thick sections. The sections were deparaffinized, rehydrated and then soaked in deionized water containing $3 \%$ hydrogen peroxide for $20 \mathrm{~min}$ to block endogenous peroxides. Then, the sections were incubated with rabbit anti-rat CRP antibody (1:400) overnight at $4^{\circ} \mathrm{C}$, and detected using Histostain-Plus kit (4 A Biotech Co., Ltd, Beijing, 

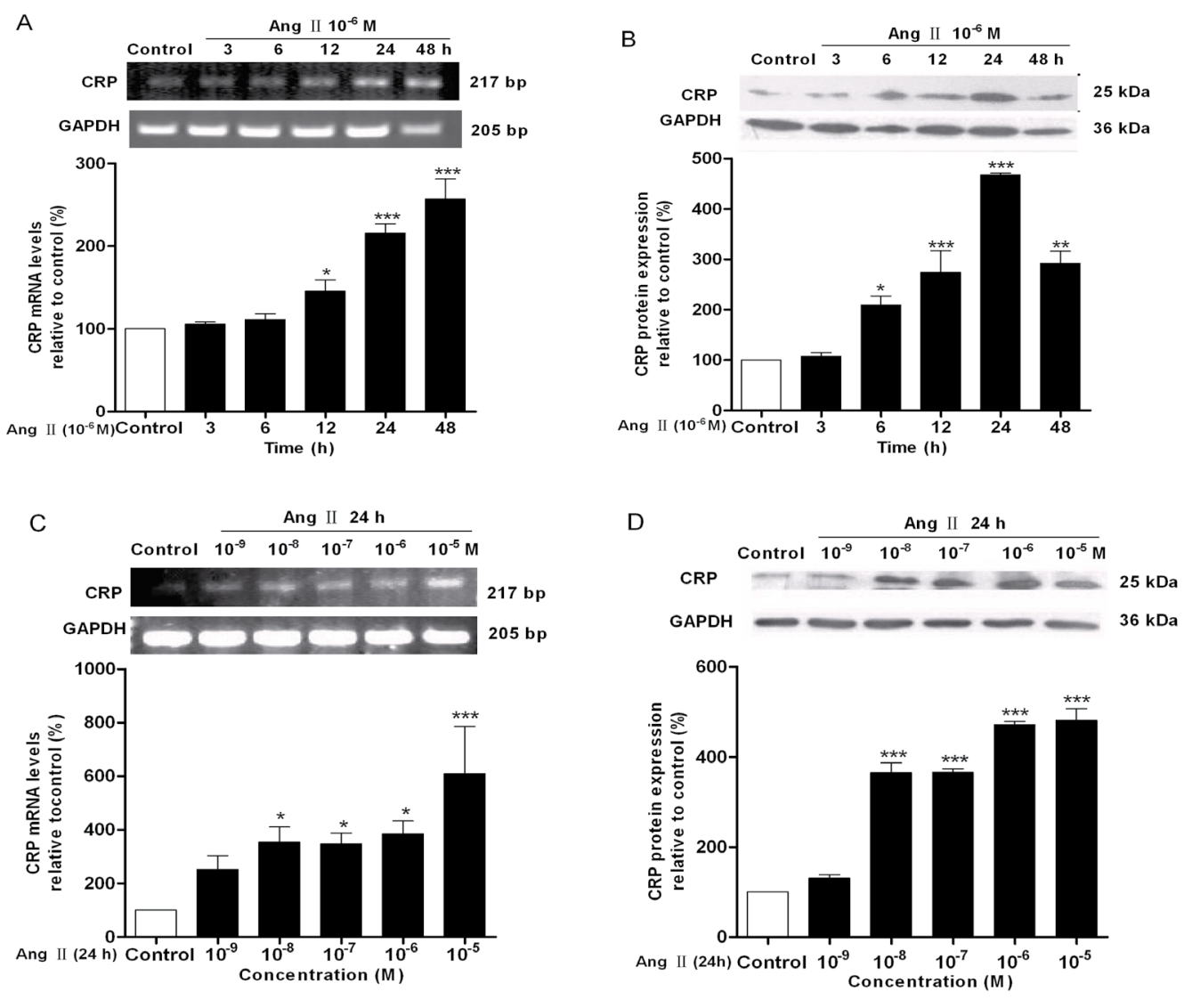

Fig. 1. Ang II-induced CRP expression in L-02 cells. (A) Time-dependent increase of CRP mRNA expression; (B) Time-dependent increase of CRP protein expression. (C) Concentration-dependent increase of CRP mRNA expression; (D) Concentration-dependent increase of CRP protein expression. The cells were treated with $10^{-6} \mathrm{M}$ Ang II for the indicated time for time-dependent experiment, or with the different concentrations of Ang II for $24 \mathrm{~h}$ for concentration-dependent experiment. Then, mRNA and protein expression of CRP was determined by RT-PCR and Western blot, respectively. Results are expressed as means \pm S.E.M (n=3). ${ }^{*} P<0.05,{ }^{* *} P<0.01$ and ${ }^{* * *} P<0.001$ vs. control.

China) with 3, 3'diaminobenzidine as the substrate. All the images were captured with an optic microscope (Eclipse E600, Nikon, Japan). Six fields per slide were randomly selected. All rats were provided by the Experimental Animal Center of Xi'an Jiaotong University College of Medicine. Animal care and procedures were performed in accordance with the Laboratory Animal Care Guidelines approved by Medical Ethics Committee of Xi'an Jiaotong University.

\section{Statistical analysis}

Results were expressed as means \pm S.E.M. Differences between groups were determined by one-way ANOVA with the SPSS 13.0 program (SPSS Inc., Chicago, IL, USA). Differences were considered significant if $P<0.05$.

\section{Results}

\section{Ang II increases CRP production in L-02 cells}

The results from Fig. 1 displayed that the unstimulated L-02 cells exhibited a very low basal mRNA and protein expression of CRP. However, Ang II at $10^{-9} \mathrm{M}$ to $10^{-6} \mathrm{M}$ caused an apparent time- and concentration-dependent increase of CRP production in L-02 cells as 

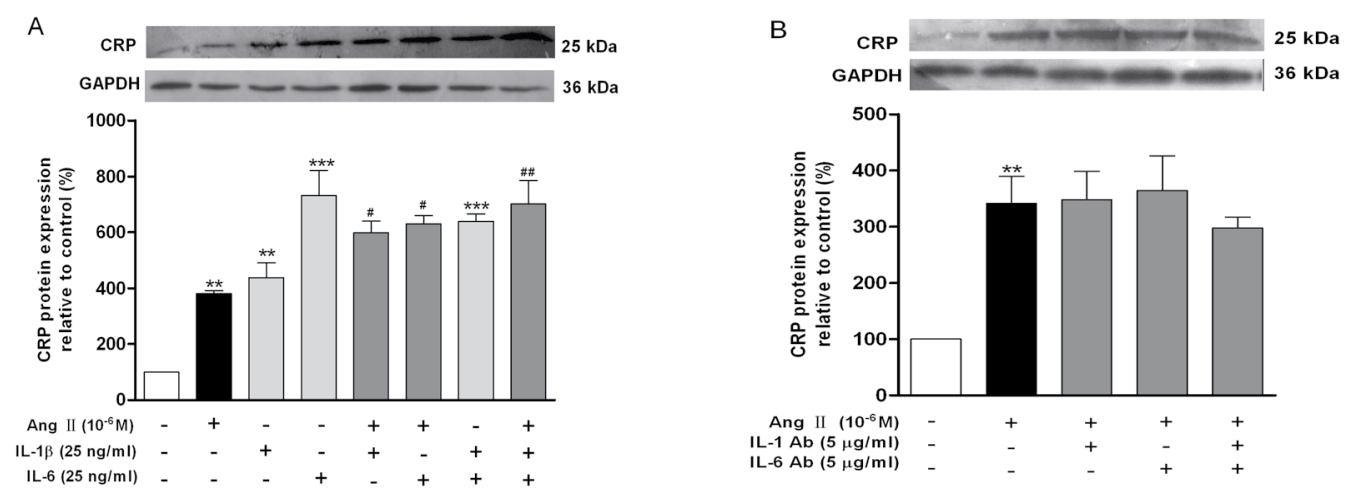

Fig. 2. Ang II -induced CRP expression in L-02 cells is independent of IL-1 $\beta$ and IL-6. (A) IL-1 $\beta$ - and IL6 -induced CRP expression in L-02 cells. The cells were treated with rhIL-6 or/and IL- $1 \beta$ for $24 \mathrm{~h}$ in the absence or presence of Ang II. (B) Effect of anti-IL-1 $\beta$ and anti-IL- 6 neutralizing antibodies on Ang II -induced CRP expression in L-02 cells. The cells were preincubated with anti-IL-6 or/and anti-IL-1 $\beta$ neutralizing antibodies for $1 \mathrm{~h}$ prior to Ang II stimulation for $24 \mathrm{~h}$. Then, CRP protein was identified by Western blot. Results are expressed as means \pm S.E.M $(\mathrm{n}=3) .{ }^{* *} P<0.01$ and ${ }^{* * *} P<0.001$ vs. control, ${ }^{\#} P<0.05$ and ${ }^{\# \#} P<0.01$ vs. Ang II.
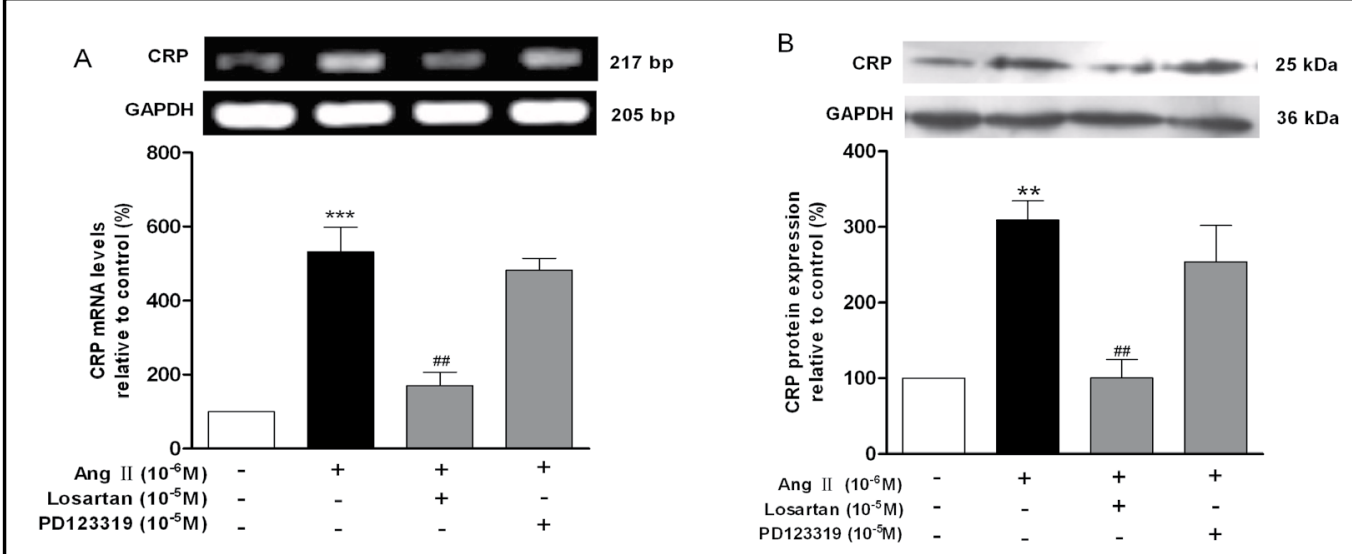

Fig. 3. Ang II induces CRP expression in L-02 cells through AT1 receptor. The cells were pretreated with AT1 receptor blocker losartan or AT2 receptor blocker PD123319 for $1 \mathrm{~h}$ prior to stimulation with Ang II for $24 \mathrm{~h}$. Then, mRNA (A) and protein (B) expression of CRP was determined by RT-PCR and Western blot, respectively. Results are expressed as means \pm S.E.M $(\mathrm{n}=3) .{ }^{* *} P<0.01$ and ${ }^{* * *} P<0.001$ vs. control, ${ }^{\# \#} P<0.01$ vs. Ang II.

compared to control. After treatment of the cells with Ang II at $10^{-6} \mathrm{M}$, mRNA and protein expression of CRP was obviously upregulated in $12 \mathrm{~h}$ or $6 \mathrm{~h}$, and reached a maximum in 48 $\mathrm{h}$ or $24 \mathrm{~h}$, which was 2.57 or 4.73 times over baseline (Fig. 1A and 1B). Similarly, following treatment of the cells with Ang II for $24 \mathrm{~h}$, mRNA and protein expression of CRP was significantly increased at $10^{-8} \mathrm{M}$, and reached the peak at $10^{-5} \mathrm{M}$ (Fig. 1C and $1 \mathrm{D}$ ), which was approximately five folds over control.

Ang II-induced CRP expression in L-02 cells is independent of IL-1 $\beta$ and IL-6

Since Ang II is known to stimulate the production of IL- $1 \beta$ and IL-6, which subsequently induce CRP expression. So we observed rhIL- 6 or/and IL-1 $\beta$-induced CRP expression in the absence or presence of Ang II $\left(10^{-6} \mathrm{M}\right)$ and whether anti-IL-1 $\beta$ or anti -IL-6 neutralizing 


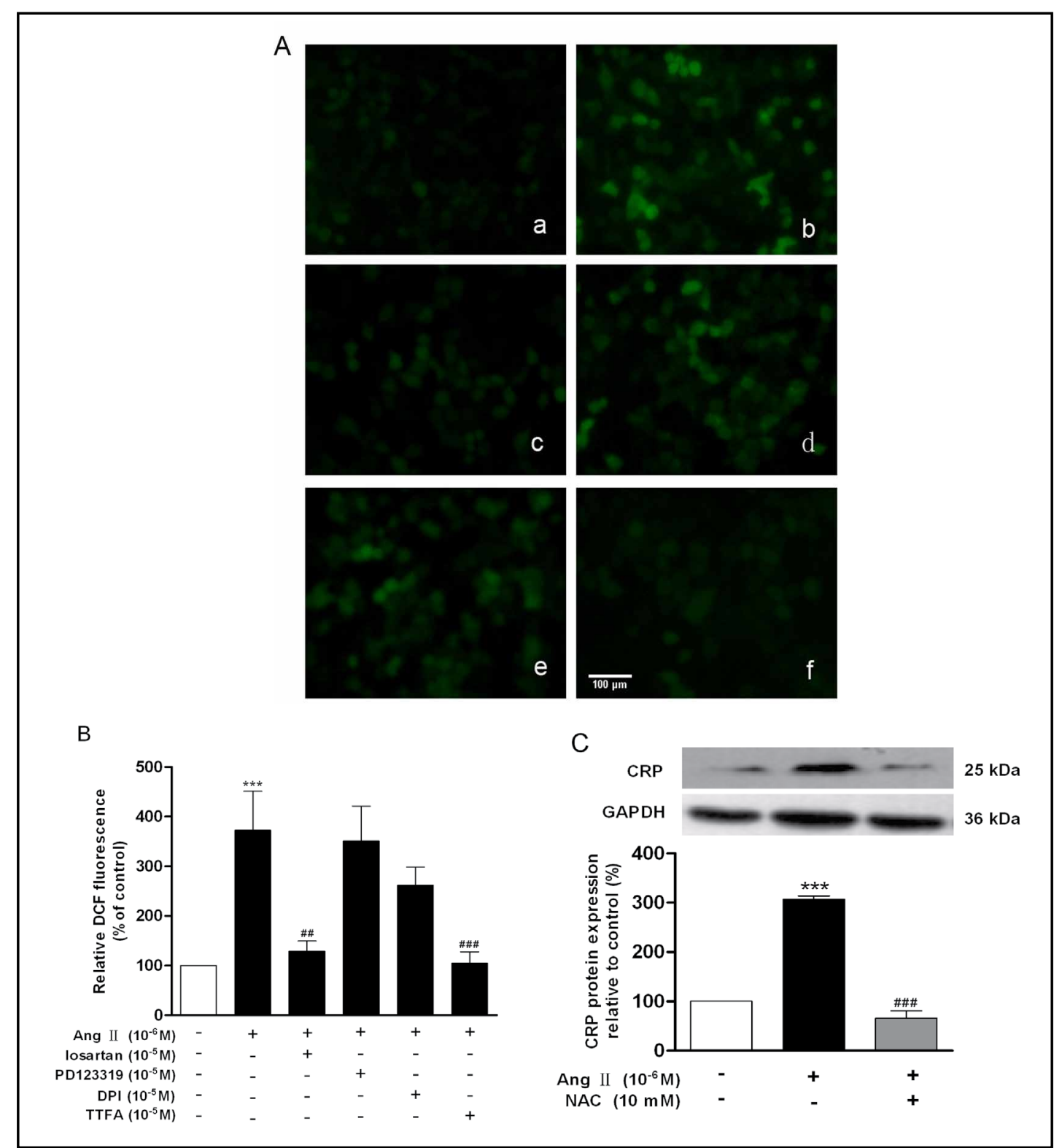

Fig. 4. Intracellular ROS is involved in Ang $I I$-induce CRP expression in L-02 cells. The cells were pretreated with the various inhibitors for $1 \mathrm{~h}$ prior to stimulation with Ang $I$ for $6 \mathrm{~h}$. Then, the cells were incubated with $\mathrm{H}_{2}$ DCF for $50 \mathrm{~min}$. Finally, the cells were observed under a fluorescence microscope. (A) Representative fluorescence images in one field: a, control; b, Ang II ; c, Ang II +losartan; d, Ang II +PD123319; e, Ang II +DPI [NAD(P)H oxidase inhibitor]; f, Ang II +TTFA (complex II inhibitor). (B) Relative fluorescence intensity quantified from the fluorescence images. (C) The cells were pretreated with antioxidant NAC for $1 \mathrm{~h}$ prior to stimulation with Ang $I I$ for $24 \mathrm{~h}$ and then, CRP protein expression was determined by Western blot. Results are expressed as means \pm S.E.M $(\mathrm{n}=6)$. ${ }^{* * *} P<0.001$ vs. control, ${ }^{\# \#} P<0.01$ and ${ }^{\# \# \#} P<0.001$ vs. Ang $\Pi$.

antibody affected Ang II-induced CRP expression in the cells. Results in Fig. 2A showed that IL- $1 \beta$ or IL- 6 alone induced CRP protein expression in L-02 cells. In the combined stimulation with IL-1 $\beta$ or/and IL- 6 and Ang II, CRP protein expression was significantly increased in comparison to Ang II. Further experiment showed that anti-IL-1 $\beta$ or/and antiIL-6 neutralizing antibodies were failed to block Ang II-stimulated CRP protein expression in the cells (Fig. 2B). 
Fig. 5. Ang II induces CRP expression in L-02 cells via AT1-ROS-MAPK-NF- $\kappa$ B signal pathway. (A) Ang $I I$ induces CRP protein expression in L-02 cells through ERK1/2, JNK and NF- $\kappa$ B. The cells were pretreated with PD98059, SP600125, SB203580 or PDTC for $1 \mathrm{~h}$ prior to Ang II stimulation for $24 \mathrm{~h}$, and then CRP protein expression was analyzed by Western blot. (B) Involvement of AT1 and ROS in Ang II -stimulated ERK1/2 activation in L-02 cells. The cells were subjected to losartan, PD123319, NAC, PD98059 for $1 \mathrm{~h}$, and then stimulated with Ang $\Pi$ for $30 \mathrm{~min}$. Total and phospho-ERK1/2 levels were analyzed by Western blot. (C) Involvement of AT1 in Ang II -stimulated JNK activation in L-02 cells. The cells were subjected to losartan, PD123319, NAC, SP600125 for $1 \mathrm{~h}$, and then stimulated with Ang II for $30 \mathrm{~min}$. Total and phospho-JNK levels were analyzed by Western blot. Results are expressed as means \pm S.E.M $(\mathrm{n}=3) .{ }^{* *} P<0.01$ and ${ }^{* * *} P<0.001$ vs. control. ${ }^{\# \#} P<0.01$ and ${ }^{\# \# \# P}<0.001$ vs. Ang II.

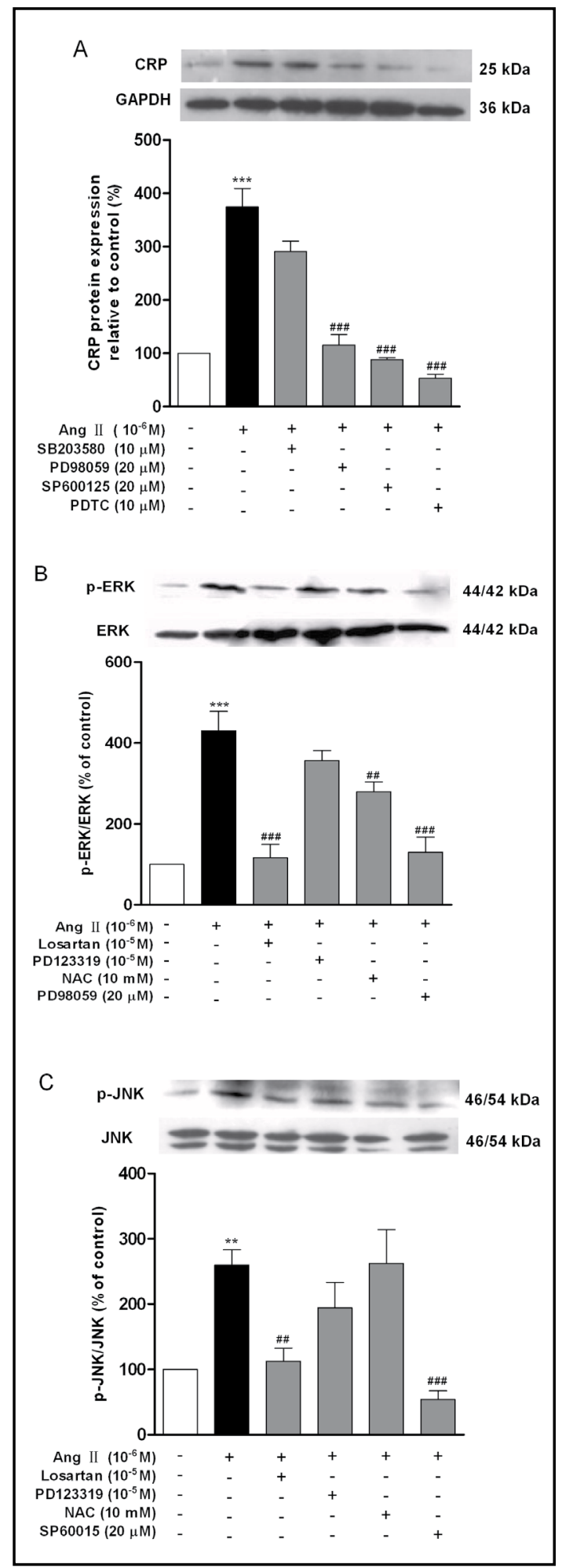

Ang II induces CRP expression in L-02 cells through AT1 receptor

After pretreatment of L-02 cells with losartan (AT1 receptor blocker) or PD123319 (AT2 receptor blocker) for $1 \mathrm{~h}$, the cells were stimulated with $10^{-6} \mathrm{M}$ Ang II for $24 \mathrm{~h}$ to determine whether Ang II receptors were involved in Ang II-induced expression of CRP. Results from Fig.3A and 3B showed that losartan apparently restrained Ang II-elicited CRP mRNA and protein accumulation in the cells, whereas PD123319 did not show a significant effect. 
Fig. 6. Ang $\Pi$-induced CRP expression in rat liver. CRP expression in hepatic tissue was detected with the immunohistochemical staining after rats reveived subcutaneous infusion of Ang II (120 ng/kg/min) or saline for 7 days. Ang $\Pi$ infusion resulted in CRP expression in plasma and nucleus (arrow) of hepatocytes. Representative CRP expression: a, control group $(100 \times) ; b$, Ang II-treated group $(100 \times) ; \quad c$, control group (200x); d, Ang II -treated group $(200 \times)$.

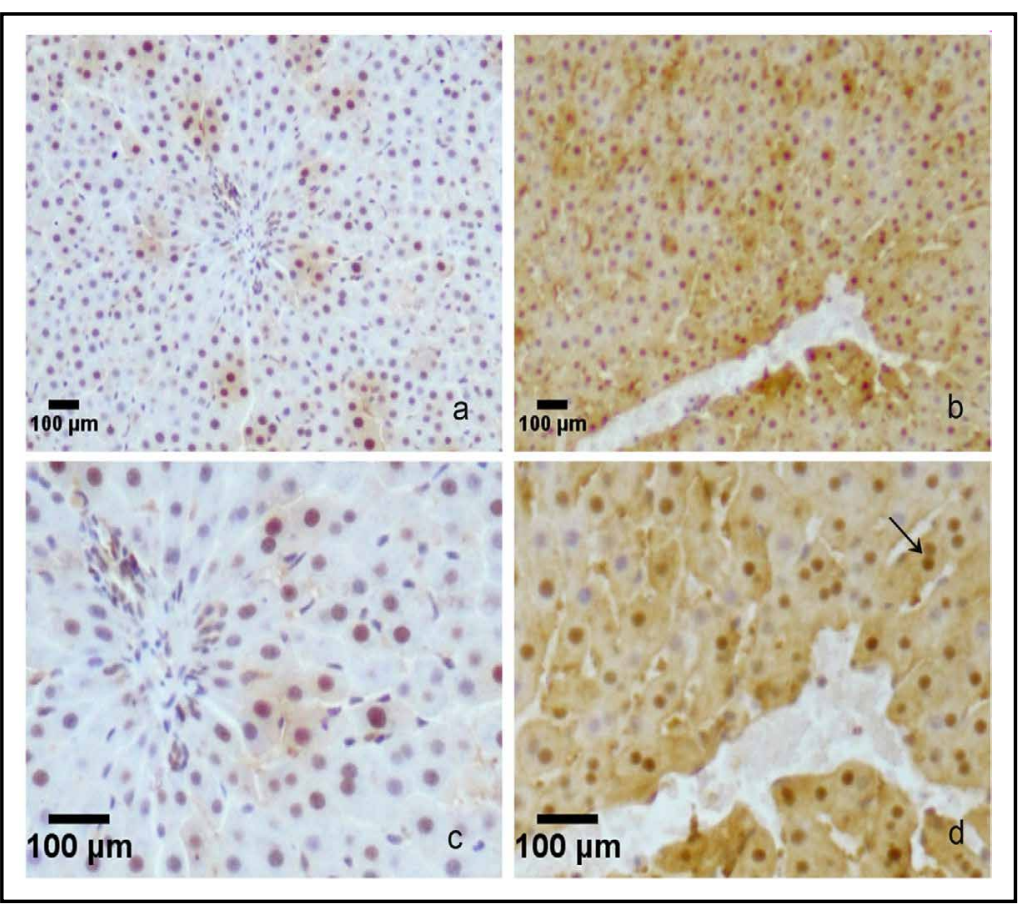

ROS is involved in Ang II-induced CRP expression in L-02 cells

As shown in Fig. 4A and 4B, there was a minor DCF fluorescence in control L-02 cells, which represented ROS generation. Exposure of the cells to Ang II resulted in a noticeable raise of ROS generation as compared to control, whereas losartan and TTFA (complex II inhibitor) obviously attenuated the effect. Although DPI [NAD(P)H oxidase inhibitor] and PD123319 tended to depress Ang II-stimulated ROS production, there was no statistical significance. This finding was further confirmed by antioxidant NAC, which was able to cancel AngII-induced CRP protein expression in the cells (Fig. 4C).

Ang II induces CRP expression in L-02 cells via MAPK-dependent signal pathway

The present experiment presented that PD98059 (ERK1/2 inhibitor), SP600125 (JNK inhibitor) or PDTC (NF- $\kappa B$ inhibitor) was able to impair Ang II-induced CRP expression in L-02 cells (Fig. 5A), whereas SB203580 (p38 MAPK inhibitor) did not show the similar effect. To further elucidate the association of ERK/JNK activation with Ang II receptors and ROS, the cells were stimulated with Ang II for 30 min after pretreatment for $1 \mathrm{~h}$ with losartan, PD123319, NAC, PD98059 or SP600125. Then, phosphorylated ERK1/2 and phosphorylated JNK expressions were determined by Western blot. As shown in Fig. 5B, losartan, NAC and PD98059 evidently inhibited Ang II-induced phosphorylation of ERK1/2, whereas PD123319 did not show a significant effect. Meanwhile, losartan and SP600125 obviously inhibited Ang II-induced phosphorylation of JNK, whereas PD123319 and NAC did not show a significantly inhibitory effect.

\section{Prolong Infusion of Ang II into rats induces CRP expression in liver}

In order to determine if Ang II had the similar effects in vivo as it did in vitro, a model of rats receiving subchronic administration of Ang II was used. The subcutaneous infusion of Ang II (120 ng/kg/min) to rats for 7 days did not markedly influence body weight and blood pressure (data not shown). However, administration of Ang II to rats elevated serum CRP from $1268.7 \pm 256.9 \mathrm{ng} / \mathrm{ml}$ to $1644.5 \pm 153.2 \mathrm{ng} / \mathrm{ml}(P<0.05)$. The immunochemistry revealed that there was a marked increase of CRP expression in liver of Ang II-infused rats in comparison with control rats (Fig.6A). The expression occurred in both cytoplasm and nucleus (arrows) of hepatocytes. 


\section{Discussion}

Multiple studies now pinpoint inflammation as a key regulatory process that links many risk factors to atherosclerosis. As a representatively inflammatory cytokine, CRP is not only an important predictor of inflammatory diseases, but also a participator in a lot of diseases including atherosclerosis. It is known that CRP is mainly produced in liver under stimulation of IL-1 $\beta$ and IL-6. Besides contribution to hepatic inflammatory diseases, CRP produced in liver is released to blood to participate in development of the systemic inflammatory response. The increased CRP level in serum is associated with atherosclerotic plaque formation and cardiovascular events [20]. High CRP level can be observed in liver tissue of some hepatic diseases, such as cirrhosis, hepatocellular carcinoma and advanced liver failure [21-23]. Chronic inflammation in the hepatic parenchyma eventually leads to fibrosis and portal hypertension [15].

Numerous clinical and laboratory data are available supporting the hypothesis that hypertension is an independent and potent risk factor for the development of atherosclerotic diseases [24]. As a potent proinflammatory agent in the vessel wall, Ang II has been widely accepted as a pivotal mediator in hypertension-induced atherosclerosis [24]. Several in vivo studies demonstrate that transiently or chronically subcutaneous infusion of Ang II activates expressions of cell adhesion molecules and chemokines, and amplifies atherosclerosis in apoE-deficient mice, which distinctly suggest a strong association between Ang II, inflammation and atherosclerosis [24, 25].

The known evidences show that Ang II also plays a role in liver inflammation both in rodents and in human. Ang II is able to exert an array of pro-inflammatory and fibrogenic actions in hepatic stellate cells [15]. There exists activation of both the systemic RAS and hepatic RAS in cirrhosis [14, 26, 27]. The increased systemic Ang II is associated with the progression of chronic liver diseases [12]. Moreover, AT1 antagonist losartan also reduces the extent of liver damage, suggesting that endogenous Ang II participates in the pathogenesis of hepatic inflammation [15].

In the present study, we found that Ang II significantly increased mRNA and protein expression of CRP in hepatocytes in time- and concentration-dependent ways. This effect was independent of IL-1 $\beta$ and IL- 6 , since pretreatment of hepatocytes with anti-IL-1 $\beta$ or anti-IL-6 neutralizing antibody did not affect Ang II-induced CRP protein expression. Our experiment also supported that IL- $1 \beta$ and IL- 6 are capable of stimulating CRP expression in hepatocyte. To test the effect of Ang II on CRP production in vivo, we used a well-characterized model of continuous infusion of Ang II into rats. The in vivo experiment showed that infusion of Ang II into rats increased CRP protein expression in liver. Further analysis suggests that Ang II-induced CRP is most probably generated in hepatocytes since the strongly positive expression of CRP was detected in the cytoplasm and nucleus of hepatocytes. Meanwhile, we observed that serum CRP was elevated in Ang II-infused rat. These indicate that Ang II contributes to the elevated circulating CRP level by stimulating hepatocytes to secrete CRP.

In vivo and in vitro studies reveal that AT1 receptor is expressed on liver parenchymal cells, i.e. hepatocytes $[13,28]$, and Ang II induces CRP production by AT1 receptor in VSMCs, HAECs and macrophages [16-18]. Therefore, Ang II possibly regulates the inflammatory response of hepatocytes via Ang II receptors. In this study, the specific AT1 receptor blocker losartan obviously inhibited Ang II- induced mRNA and protein expression of CRP in hepatocytes, whereas AT2 receptor blocker PD123319 did not alter the effect of Ang II on CRP both in mRNA and in protein levels, demonstrating stimulation by Ang II of CRP production via activating AT1 receptor.

It is all known that ROS, as an important intracellular second messenger, mediate the generation of inflammatory cytokines through activating many downstream signaling molecules including MAPK [29, 30]. Ang II increases ROS generation via AT1 receptors [30]. The results of the present experiment exhibited that Ang II stimulated ROS production in hepatocytes mainly via AT1 and mitochondria-derived pathway, since AT1 receptor blocker losartan and mitochondrial respiratory complex II inhibitor TTFA markedly antagonized the 
stimulatory effect of Ang II on ROS production, while AT2 receptor blocker PD123319 and NAD (P) H oxidase inhibitor DPI slightly inhibited Ang II-stimulated ROS generation. These results are in line with other researches [30,31]. Additionally, antioxidant NAC completely inhibited Ang II-induced CRP protein expression. These demonstrate that Ang II-induced CRP expression in hepatocytes involves AT1 receptor and subsequent ROS.

MAPK-dependent signaling pathway is linked with the inflammatory process of cardiovascular and liver diseases. Ang II is able to activate p38 MAPK, ERK1/2 and JNK in VSMCs [32-34]. Our results displayed that Ang II activated ERK1/2 and JNK phosphorylation in hepatocytes, which is consistent with the results in Ang II-infused rats [12]. Since AT1 receptor blocker losartan and antioxidant NAC significantly inhibited Ang II-activated ERK1/2 phosphorylation in hepatocytes, it is suggested that Ang II-activated ERK1/2 phosphorylation is mediated by AT1 receptor and ROS. However, AT1 receptor blocker losartan, but not NAC, significantly inhibited Ang II-activated JNK phosphorylation, which mean that Ang II-activated JNK phosphorylation is mediated by AT1 receptor, not ROS. Furthermore, ERK1/2 inhibitor PD98059 and JNK inhibitor SP600125 evidently reduced Ang II-induced CRP protein expression, implicating that ERK1/2 and JNK, but not p38 MAPK, is necessary for Ang II-induced CRP expression in hepatocytes.

Growing data confirm a potential role of NF- $\mathrm{KB}$ as a mediator of Ang II-induced inflammatory process. Systemic infusion of Ang II into normal rats activates NF- $\kappa B$ in liver [12]. Voleti and Agrawal demonstrate that NF- $\kappa B$ is involved in IL-6-stimulated CRP expression in hepatocytes as well [35]. NF- $\kappa B$ activation is considered to be a downstream event of MAPK [36, 37]. In this study, NF- $\kappa B$ inhibitor PDTC significantly inhibited Ang IIinduced CRP protein expression in hepatocytes, inferring involvement of NF- $\kappa B$ in Ang IIinduced CRP generation.

In summary, our data demonstrate that Ang II has ability to induce CRP expression in hepatocytes both in vitro and in vivo, which is mediated predominately through AT1 receptor followed by ROS, MAPK and NF- $\kappa$ B signal pathway. This finding has both pathological significance and clinical implication. On the one hand, the result provides a new evidence for the proinflammatory effect of Ang II in liver, and emphasizes importance of Ang IICRP signaling in inflammatory pathogenesis of chronic liver diseases and atherosclerotic diseases. On the other hand, our result suggests the possibility that blockade of RAS in liver by angiotensin converting enzyme inhibitor or AT1 receptor blocker is a new therapeutic strategy for the inflammatory hepatic diseases, especially for patients with chronic liver diseases and high RAS activity.

\section{Acknowledgements}

This study was supported by Scholarship of Ministry of Education of China for Excellent Doctoral postgraduate.

\section{References}

1 Ridker PM, Rifai N, Rose L, Buring JE, Cook NR: Comparison of C-reactive protein and low-density lipoprotein cholesterol levels in the prediction of first cardiovascular events. N Engl J Med 2002;347:15571565.

2 Devaraj S, Singh U, Jialal I: The evolving role of C-reactive protein in atherothrombosis. Clin Chem 2009;55:229-238.

3 Hein TW, Singh U, Vasquez-Vivar J, Devaraj S, Kuo L, Jialal I: Human C-reactive protein induces endothelial dysfunction and uncoupling of eNOS in vivo. Atherosclerosis 2009;206:61-68.

4 Majello B, Arcone R, Toniatti C, Ciliberto G: Constitutive and IL-6-induced nuclear factors that interact with the human C-reactive protein promoter. Embo J 1990;9:457-465. 
5 Kleemann R, Gervois PR, Verschuren L, Staels B, Princen HMG, Kooistra T: Fibrates down-regulate IL-1stimulated C-reactive protein gene expression in hepatocytes by reducing nuclear p50-NF kappa B-C/EBPbeta complex formation. Blood 2003;101:545-551.

6 Radtke S, Wueller S, Yang X-p, Lippok BE, Muetze B, Mais C, Schmitz-Van de Leur H, Bode JG, Gaestel M, Heinrich PC, Behrmann I, Schaper F, Hermanns HM: Cross-regulation of cytokine signalling: Proinflammatory cytokines restrict IL-6 signalling through receptor internalisation and degradation. J Cell Sci 2010;123:947-959.

7 Ivashchenko Y, Kramer F, Schafer S, Bucher A, Veit K, Hombach V, Busch A, Ritzeler O, Dedio JR, Torzewski J: Protein kinase $C$ pathway is involved in transcriptional regulation of $C$-reactive protein synthesis in human hepatocytes. Arterioscler Thromb Vasc Biol 2005;25:186-192. Black S, Kushner I, Samols D: C-reactive protein. J Biol Chem 2004;279:48487-48490.

Marrero MB, Schieffer B, Paxton WG, Heerdt L, Berk BC, Delafontaine P, Bernstein KE: Direct stimulation of JAK/STAT pathway by the angiotensin- II AT(1) receptor. Nature 1995;375:247-250.

10 Suzuki Y, Ruiz-Ortega M, Lorenzo O, Ruperez M, Esteban V, Egido J: Inflammation and angiotensin II. Int J Biochem Cell Biol 2003;35:881-900.

11 Ruiz-Ortega M, Lorenzo O, Suzuki Y, Ruperez M, Egido J: Proinflammatory actions of angiotensins. Curr Opin Nephrol Hypertens 2001;10:321-329.

12 Bataller R, Gabele E, Schoonhoven R, Morris T, Lehnert M, Yang L, Brenner DA, Rippe RA: Prolonged infusion of angiotensin $\Pi$ into normal rats induces stellate cell activation and proinflammatory events in liver. Am J Physiol-Gastrointest Liver Physiol 2003;285:G642-G651.

13 Bataller R, Sancho-Bru P, Gines P, Lora JM, Al-Garawi A, Sole M, Colmenero J, Nicolas JM, Jimenez W, Weich N, Gutierrez-Ramos JC, Arroyo V, Rodes J: Activated human hepatic stellate cells express the reninangiotensin system and synthesize angiotensin II. Gastroenterology 2003;125:117-125.

14 Paizis G, Cooper ME, Schembri JM, Tikellis C, Burrell LM, Angus PW: Up-regulation of components of the renin-angiotensin system in the bile duct-ligated rat liver. Gastroenterology 2002;123:1667-1676.

15 Moreno M, Ramalho LN, Sancho-Bru P, Ruiz-Ortega M, Ramalho F, Abraldes JG, Colmenero J, Dominguez M, Egido J, Arroyo V, Gines P, Bataller R: Atorvastatin attenuates angiotensin II -induced inflammatory actions in the liver. Am J Physiol-Gastrointest Liver Physiol 2009;296:G147-G156.

16 Peng N, Liu J-T, Gao D-F, Lin R, Li R: Angiotensin II -induced C-reactive protein generation: Inflammatory role of vascular smooth muscle cells in atherosclerosis. Atherosclerosis 2007;193:292-298.

17 Han C, Liu J, Liu X, Li M: Angiotensin II induces C-reactive protein expression through ERK1/2 and JNK signaling in human aortic endothelial cells. Atherosclerosis 2010;212:206-212.

18 Li M, Liu J, Han C, Wang B, Pang X, Mao J: Angiotensin II induces the expression of C-reactive protein via MAPK-dependent signal pathway in U937 macrophages. Cell Physiol Biochem 2011;27:63-70.

19 Li JT, Hou FF, Guo ZJ, Shan YX, Zhang X, Liu ZQ: Advanced glycation end products upregulate C-reactive protein synthesis by human hepatocytes through stimulation of monocyte IL- 6 and IL-1 beta production. Scand J Immunol 2007;66:555-562.

20 Pepys MB, Hirschfield GM, Tennent GA, Gallimore JR, Kahan MC, Bellotti V, Hawkins PN, Myers RM, Smith MD, Polara A, Cobb AJA, Ley SV, Aquilina JA, Robinson CV, Sharif I, Gray GA, Sabin CA, Jenvey MC, Kolstoe SE, Thompson D, Wood SP: Targeting C-reactive protein for the treatment of cardiovascular disease. Nature 2006;440:1217-1221.

-21 Bota DP, Van Nuffelen M, Zakariah AN, Vincent JL: Serum levels of C-reactive protein and procalcitonin in critically ill patients with cirrhosis of the liver. J Lab Clin Med 2005;146:347-351.

22 Cervoni J-P, Thévenot T, Weil D, Muel E, Barbot O, Sheppard F, Monnet E, Di Martino V: C-reactive protein predicts short-term mortality in patients with cirrhosis. J Hepatol 2012;56:1299-1304.

23 Jang JW, Oh BS, Kwon JH, You CR, Chung KW, Kay CS, Jung HS: Serum interleukin-6 and C-reactive protein as a prognostic indicator in hepatocellular carcinoma. Cytokine 2012;60:686-693.

24 Ayabe N, Babaev VR, Tang YW, Tanizawa T, Fogo AB, Linton MF, Ichikawaa I, Fazio S, Kon V: Transiently heightened angiotensin $\Pi$ has distinct effects on atherosclerosis and aneurysm formation in hyperlipidemic mice. Atherosclerosis 2006;184:312-321.

25 Cunha DV, Tham MD, Martin-Mcnulty B, Deng G, Ho JJ, Wilson DW, Rutledge JC, Vergona R, Sullivan ME, Wang YX: Enalapril attenuates angiotensin II-induced atherosclerosis and vascular inflammation. Atherosclerosis 2005;178:9-17. 
Zhao et al.: Angiotensin II Induces CRP via MAPK

26 Herath CB, Warner FJ, Lubel JS, Dean RG, Jia Z, Lew RA, Smith AI, Burrell LM, Angus PW: Upregulation of hepatic angiotensin-converting enzyme 2 (ACE2) and angiotensin-(1-7) levels in experimental biliary fibrosis. J Hepatol 2007;47:387-395.

27 Paizis G, Tikellis C, Cooper ME, Schembri JM, Lew RA, Smith AI, Shaw T, Warner FJ, Zuilli A, Burrell LM, Angus PW: Chronic liver injury in rats and humans upregulates the novel enzyme angiotensin converting enzyme 2. Gut 2005;54:1790-1796.

-28 Schulte S, Oidtmann A, Kociok N, Demir M, Odenthal M, Drebber U, Dienes H-P, Nierhoff D, Goeser T, Toex $\mathrm{U}$, Steffen H-M: Hepatocyte expression of angiotensin II type 1 receptor is downregulated in advanced human liver fibrosis. Liver Int 2009;29:384-391.

-29 Wei Y, Chen K, Whaley-Connell AT, Stump CS, Ibdah JA, Sowers JR: Skeletal muscle insulin resistance: Role of inflammatory cytokines and reactive oxygen species. Am J Physiol-Regul Integr Comp Physiol 2008;294:R673-R680.

-30 Zhang G-X, Lu X-M, Kimura S, Nishiyama A: Role of mitochondria in angiotensin II -induced reactive oxygen species and mitogen-activated protein kinase activation. Cardiovasc Res 2007;76:204-212.

31 Hsu YH, Chen JJ, Chang NC, Chen CH, Liu JC, Chen TH, Jeng CJ, Chao HH, Cheng TH: Role of reactive oxygen species-sensitive extracellular signal-regulated kinase pathway in angiotensin $\Pi$-induced endothelin-1 gene expression in vascular endothelial cells. J Vasc Res 2004;41:64-74.

-32 Griendling KK, Ushio-Fukai M: Reactive oxygen species as mediators of angiotensin II signaling. Regul Pept 2000;91:21-27.

33 Ushio-Fukai M, Alexander RW, Akers M, Griendling KK: P38 mitogen-activated protein kinase is a critical component of the redox-sensitive signaling pathways activated by angiotensin $\Pi$ - role in vascular smooth muscle cell hypertrophy. J Biol Chem 1998;273:15022-15029.

-34 Viedt C, Soto U, Krieger-Brauer HI, Fei JW, Elsing C, Kubler W, Kreuzer J: Differential activation of mitogenactivated protein kinases in smooth mascle cells by angiotensin $I$ - involvement of p22phox and reactive oxygen species. Arterioscler Thromb Vasc Biol 2000;20:940-948.

-35 Voleti B, Agrawal A: Regulation of basal and induced expression of c-reactive protein through an overlapping element for OCT-1 and NF-kappa B on the proximal promoter. J Immunol 2005; 175:33863390.

-36 Patel DN, King CA, Bailey SR, Holt JW, Venkatachalam K, Agrawal A, Valente AJ, Chandrasekar B: Interleukin-17 stimulates C-reactive protein expression in hepatocytes and smooth muscle cells via p38 MAPK and ERK1/2-dependent NF-kappa B and C/EBP beta activation. J Biol Chem 2007;282:27229-27238.

37 Liu C-M, Sun Y-Z, Sun J-M, Ma J-Q Cheng C: Protective role of quercetin against lead-induced inflammatory response in rat kidney through the ROS-mediated MAPKs and NF-kappa B pathway. Biochim Biophys Acta 2012;1820:1693-1703. 